\title{
Diagnostic, Treatment and Recovery of Early Infections After ACL Reconstruction \\ A retrospective study
}

\author{
VLAD GEORGEANU ${ }^{1,3}$, RADU COPACIU1*, TUDOR ATASIEI $^{1,3}$, DINU GARTONEA ${ }^{1}$, BEHROZ SHAHZAD ${ }^{1}$, GABRIEL SHAHZAD $^{1}$, \\ OANA SANDULESCU2,3 \\ ${ }^{1}$ Clinical Emergency Hospital Sf. Pantelimon, 340-342 Pantelimon Road, 021659, Bucharest Romania \\ ${ }^{2}$ National Institute for Infectious Diseases Prof. Dr. Matei Bals, 1 Dr. Calistrat Grozovici, 021105, Bucharest Romania \\ ${ }^{3}$ Carol Davila University of Medicine and Pharmacy, 8 Eroii Sanitari Blvd., 050474, Bucharest Romania
}

The ACL reconstruction is usually a safe procedure and infection is rather uncommon. Despite this, when infection occurs, it has a devastating potential for the knee joint which can result in a poor clinical outcome. Treatment protocol differs, and optimal management has not been established. The purpose of the study was to determine the incidence of postoperative infections after ACL reconstruction on 262 cases of arthroscopic ACL reconstructions which were operated in a period of 4 years (2014-2017), with a follow-up period of minimum 12 months. Six cases (2.29\%) with infections were identified and analyzed in regard to clinical presentation, microbiological findings and therapeutic approach. In three out of six cases the germ identified in the aspirate from the joint was coagulase-negative staphylococci (50\%); other germs were gr. D. Streptococcus (16\%) and E. Coli (16\%). In one case, we did notidentify the germ. The surgical intervention was conducted in the first $12 \mathrm{~h}$ from admission. All these cases underwent aggressive arthroscopic debridement and antibiotic treatment. Eradication was achieved in all patients with graft retention in 5 cases (83.3\%) and graft removal in one case. The mean duration of antibiotic treatment was 6 weeks and no recurrence of the infection was seen.

Keywords: ACL reconstruction, knee joint, postoperative infections, germ

The $A C L$ injury is the most frequent ligamentous knee injury [1]. After the injury, ACL reconstruction by arthroscopic surgery is a very efficient method to restore the knee stability, but like any other surgical procedure, it can associate with a number of complications which, if they occur, may have an impact on the functional and clinical outcome of the patient $[2,3]$. According to recent literature, septic arthritis incidence rate is reported to range from $0.14 \%$ to $1.8 \%[4,5]$. The most severe complications of knee infections are cartilage lesions, diffuse chondral thinning, osteoarthritis, and osteomyelitis [6,7]. In less than 7 days from the beginning of the infection, the cartilage loses more than half of its collagen and glycosaminoglycan [6], that is why early diagnosis and treatmentare extremely important to facilitate the healing process and to avoid a poor outcome. Another issue is deciding whether or not to keep the graft in the presence of infection; there is still some controversy on this topic. A general consensus has been achieved regarding the positive impact of early antibiotic therapy on the preservation of articular cartilage. Although the current treatment options include open or arthroscopic surgery with graft preservation or removal and long-term antibiotic therapy, an agreement regarding the best practices for managing knee infection is yet to be achieved due to lack of conclusive evidence. Furthermore, as most studies on this topic have only focused on the outcomes in terms of healing the infection, data on the functional outcome of the joint is scarce $[8,9]$.

The purpose of our study was to determine the incidence of postoperative infections after $A C L$ reconstruction and to identify the appropriate treatment which can provide the best outcome for the patient and to present our approach to the mentioned condition.

\section{Experimental part}

We performed a retrospective study consisting of a review of 6 infected cases (2.29\%) of 262 arthroscopic ACL reconstructions that occurred between J anuary 2014 and October 2017 in one hospital. Cases that presented post-operative infections were identified and analyzed in terms of clinical presentation, microbiological findings, time to and number of arthroscopic reinterventions and evolution. We included in the analysis all cases that had a follow-up period of minimum 12 months (table 1).

\begin{tabular}{|c|c|c|c|c|c|}
\hline Cases of SA & Gender & Age & Graft type & Organism & Additional procedure \\
\hline Patient A & M & 25 & soft-tissue & $\mathrm{CNS}$ & - \\
\hline Patient $\mathrm{B}$ & $\mathrm{M}$ & 40 & soft-tissue & $\mathrm{CNS}$ & Partial $^{-}$meniscectomy \\
\hline Patient $\mathrm{C}$ & $\mathrm{F}^{-}$ & 26 & soft-tissue & No identified germ & - \\
\hline Patient D & $\mathrm{M}$ & $23^{-}$ & soft-tissue & E. coli & - \\
\hline Patient $\mathrm{E}^{-}$ & $\mathrm{M}$ & 39 & soft-tissue & Group D Streptococcus & - \\
\hline Patient $\mathrm{F}$ & $\mathrm{M}^{-}$ & 26 & soft-tissue & $\mathrm{CNS}^{-}$ & Partial meniscectomy \\
\hline
\end{tabular}

Table 1

CHARACTERISTICS OF THE SIX CASES OF PATIENTS WHO PRESENTED POST-OPERATIVE INFECTIONS FOLLOWING ACL RECONSTRUCTION 
The follow-up examination consisted of clinical examination, inflammatory tests, imagistic investigation and functional assessment based on Lysholm Knee Scoring Scale, Tegner Activity Scale and subjective aspects (VASVisual Analogue Scale for pain during activity) as well.

All reconstructions were performed with autologous grafts: 246 using soft-tissue grafts (semitendinosus and gracilis tendons) and 16 were made using bone-tendonbone (patellar tendon) grafts. A unitary surgical technique was used with all patients. For the soft tissue reconstruction, the femoral canal was prepared through the anteromedial portal and the femoral fixation was made using a suspension technique. The tibial canal was made through the harvest incision. For the tibial fixation, only interference screws were used. For the BTB technique, the graft was harvested through a 5-6 cm incision centered on the patellar tendon. Both femoral and tibial plugs were fixed with interference screws. The graft site was then filled using bone chips from the tibial tunnel. For all patients, intraarticular active drains were used for 24 hours.

Antibiotic prophylaxis consisted of a third-generation cephalosporin (ceftriaxone); 158 patients were given 2 grams of ceftriaxone, as a single dose, in the preoperative period, $60 \mathrm{~min}$ before the procedure. The other 104 patients were given additional 2 grams of antibiotic after $12 \mathrm{~h}$ due to prolonged operation time (over 90 minutes). The duration of the surgery was between 45 and $100 \mathrm{~min}$. There was no statistically significant difference between the two groups in the rate of infections. The instruments were sterilized by autoclaving, and the camera and shaver blades were sterilized by soaking them in activated glutaraldehyde solution.
Among the 6 cases of post-operative infections, 5 were males and 1 was female. The age of the patients ranged between 23 and 48 years, and all had undergone soft-tissue reconstruction. Only 2 of the patients diagnosed with infection had had additional surgery (partial meniscectomy) during the same intervention.

In three out of six cases the germ identified was coagulase-negative Staphylococcus; group D Streptococcus was isolated in the joint aspirate from 1 patientand $E$. coli was identified in 1 patient. In one patient, no germ was identified. The laboratory values (table 2) showed an increase in the erythrocyte sedimentation rate (ESR 45-86 mm/1h), CRP (69.5-206.10 mg/L), and white blood cells (WBC: 7800-12870/ $\mu \mathrm{L}$ ). Blood cultures were negative in all cases.

The surgical debridement was performed in the first 12 hours after admission, through an arthroscopic approach, with two standard anterior portals. Devitalized or necrotic tissue was debrided and fibrin layers as well as coagulated blood clots were removed, prior to irrigation with 8-10 L of saline solution [10]. An active-suction drain was placed in the joint for three days. The graft was retained in all cases at the first debridement. After collecting samples for cultures, empirical antimicrobial therapy was started intravenously, with of a third-generation cephalosporin (ceftriaxone) and vancomycin. Antimicrobial treatment was revised according to bacteriological results and the susceptibility profile of the identified germs. After the completion of IV antibiotics for a period of time between 3 and 4 weeks, treatment was continued orally, for a total duration of 6 weeks (table 3).

\begin{tabular}{|c|c|c|c|c|}
\hline & CRP & ESR & WBC & Organism \\
\hline Patient $\mathrm{A}$ & 206.10 & 78 & 12870 & $\mathrm{CNS}$ \\
\hline Patient B & 156.2 & 82 & $9870^{-}$ & $\mathrm{CNS}^{-}$ \\
\hline Patient $\mathrm{C}$ & 69.50 & 45 & $10941^{-}$ & No identified germ \\
\hline Patient D & 168.50 & 67 & 11370 & E. coli \\
\hline Patient $\mathrm{E}$ & $154^{-}$ & 72 & 7800 & Group D Streptococcus \\
\hline Patient $\mathrm{F}$ & 92 & 86 & $9620^{-}$ & $\mathrm{CNS}$ \\
\hline
\end{tabular}

Table 2

ADMISSION LABORATORY DATA VS. ORGANISM

$\mathrm{ESR}=$ erythrocyte sedimentation rate; $\mathrm{WBC}=$ white blood cells; CNS = coagulase-negative staphylococci

\begin{tabular}{|c|c|c|c|c|c|}
\hline Patient & $\begin{array}{l}\mathrm{AB} \text { prior to } \\
\text { surgery }\end{array}$ & Organism & Postop AB & Duration & $\begin{array}{l}\text { Outpatient treatment } \\
\text { (oral) }\end{array}$ \\
\hline A & $\begin{array}{l}\text { Ceftriaxone 2g IV } \\
\text { Vancomycin 1g IV }\end{array}$ & $\mathrm{CNS}$ & Vancomycin 2g/day IV & 4 weeks & $\begin{array}{l}\text { Clindamycin } \\
1.8 \mathrm{~g} / \text { day, } 2 \text { weeks }\end{array}$ \\
\hline B & $\begin{array}{l}\text { Ceftriaxone } 2 \mathrm{~g} \mathrm{IV} \\
\text { Vancomycin } 1 \mathrm{~g} \mathrm{IV}\end{array}$ & $\mathrm{CNS}^{-}$ & Vancomycin $2 \mathrm{~g} /$ day IV & 4 weeks & $\begin{array}{l}\text { Clindamycin } \\
1.8 \mathrm{~g} / \text { day, } 2 \text { weeks }\end{array}$ \\
\hline $\mathrm{C}^{-}$ & $\begin{array}{l}\text { Ceftriaxone } 2 \mathrm{~g} \mathrm{IV} \\
\text { Vancomycin } 1 \mathrm{~g} \mathrm{IV}\end{array}$ & $\begin{array}{l}\text { No identified } \\
\text { germ }\end{array}$ & $\begin{array}{l}\text { Ceftriaxone } 2 \mathrm{~g} / \text { day IV } \\
\text { Vancomycin } 2 \mathrm{~g} / \text { day IV }\end{array}$ & 4 weeks & $\begin{array}{l}\text { Levofloxacin } 750 \\
\mathrm{mg} / \text { day plus rifampin } \\
900 \mathrm{mg} / \text { day, } 2 \text { weeks }\end{array}$ \\
\hline D & $\begin{array}{l}\text { Ceftriaxone } 2 \mathrm{~g} \mathrm{IV} \\
\text { Vancomycin } 1 \mathrm{~g} \mathrm{IV}\end{array}$ & E. coli & Ceftriaxone $2 \mathrm{~g} /$ day IV & 4 weeks & $\begin{array}{l}\text { Ciprofloxacin } 1 \mathrm{~g} / \mathrm{day} \text {, } \\
2 \text { weeks }\end{array}$ \\
\hline$E$ & $\begin{array}{l}\text { Ceftriaxone } 2 \mathrm{~g} \mathrm{IV} \\
\text { Ciprofloxacin } 400 \\
\text { mg IV }\end{array}$ & $\begin{array}{l}\text { Group D } \\
\text { Streptococcus }\end{array}$ & Imipenem $2 \mathrm{~g}$ day IV & 4 weeks & $\begin{array}{l}\text { Ciprofloxacin } 1 \mathrm{~g} / \text { day, } \\
2 \text { weeks }\end{array}$ \\
\hline$F$ & $\begin{array}{l}\text { Ceftriaxone } 2 \mathrm{~g} \mathrm{IV} \\
\text { Vancomycin 1g IV }\end{array}$ & $\mathrm{CNS}^{-}$ & Vancomycin 2g/day IV & 4 weeks & $\begin{array}{l}\text { Clindamycin } \\
1.8 \mathrm{~g} / \text { day, } 2 \text { weeks }\end{array}$ \\
\hline
\end{tabular}

Table 3 ANTIBIOTIC THERAPY PROTOCOL 
Table 4

TREATMENT OPTIONS AND EVOLUTION

\begin{tabular}{|c|c|c|c|c|c|c|c|}
\hline Patient & $\begin{array}{l}\text { Hospital } \\
\text { days }\end{array}$ & Organism & $\begin{array}{l}\text { No. of } \\
\text { procedures }\end{array}$ & $\begin{array}{l}\text { Tíme } \\
\text { between } \\
\text { procedures } \\
\text { (days) }\end{array}$ & $\begin{array}{l}\text { Graft } \\
\text { retention }\end{array}$ & $\begin{array}{l}\text { Time to CRP } \\
\text { normalization } \\
\text { (days) }\end{array}$ & $\begin{array}{l}\text { Graft } \\
\text { revision }\end{array}$ \\
\hline A & 14 & CNS & 1 & - & yes & 27 & no \\
\hline $\mathrm{B}$ & 12 & $\mathrm{CNS}^{-}$ & 1 & - & yes & 35 & no \\
\hline $\mathrm{C}$ & 16 & $\begin{array}{l}\text { No identified } \\
\text { germ }\end{array}$ & 1 & - & yes & $23^{-}$ & no \\
\hline $\mathrm{D}$ & 11 & E. coli & 1 & - & yes & 22 & no \\
\hline $\mathrm{E}$ & 22 & $\begin{array}{l}\text { Group D } \\
\text { Streptococcus }\end{array}$ & 2 & 7 & no & 41 & yes \\
\hline $\mathrm{F}$ & 14 & $\mathrm{CNS}^{-}$ & 1 & - & yes & 25 & no \\
\hline
\end{tabular}

Postoperative evolution was appreciated according to the results of daily physical examination and the dynamics of CRP, ESR and WBC blood levels, checked every 3 days. Although Calvisi and Lupparelli [11] reported some fluctuations in the levels of CRP in a series of 58 patients who underwent $A C L$ reconstruction without developing any infections, this parameter seems to remain the most reliable in the diagnostic of joint infections [12]. In the same time CRP is the most sensitive marker of septic evolution; it usually decreased between 3 to 6 weeks [10] (table 4).

After clinical and laboratory improvement, continuous passive motion was started at a slower rate than the standard protocol. In the first 3 to 5 days, passive flexion/ extension at 0-60 degrees was allowed, with isometric contractions of the quadriceps, followed by increase of flexion at 90 degrees and active movements.

Following discharge, patients returned on a weekly basis for 6 weeks for follow-up examinations who includes clinical aspect (pain, mobility, muscular strength recovery), laboratory tests (PCR, ESR). After this period, a monthly examination is scheduled for the first 6 months, and at 3 months until one year from the joint debridement.

\section{Results and discussions}

According to our findings, $A C L$ reconstruction is usually a safe procedure having a low risk of infection (2.29\%). We also found that septic arthritis, when it occurs, can be successfully treated by arthroscopic procedures associated with specific antibiotherapy, which can lead to graft preservation and good functional outcomes. In the literature, the prevalence of septic arthritis following primary $A C L$ reconstruction ranges from 0.14 to $1.7 \%[5$, 13-15]. In their study, Sonnery-Cottet et al. [16] reported that the incidence of knee joint infection after $A C L$ reconstruction alone was $0.37 \%$; The study also included professional athletes and in those series, the prevalence of knee infection was $5.7 \%$. Because almost one quarter of the athletes in their study had undergone a combined lateral tenodesis, the authors stated that having this additional procedure during $A C L$ reconstruction carries higher odds of developing an infection. Currently, post-ACL the pathogenesis of infection following reconstruction is considered multifactorial, as ACL grafts are foreign bodies. Although none of the patients assessed in our study had harvest site infection, all of the infected cases had the reconstruction done with autologous hamstring tendon graft which confirms the literature that this type of graft is more susceptible to infection compared to a bone-patellar tendon-bone (BPTB) graft [17].

On admission, all the patients in our study showed typical signs suggestive of infection. The symptoms started between 10 and 19 days from the initial favorable postoperative evolution. The time span elapsed between the first symptom and admission was an average of 24 hours. The major complaints were pain, decreased active joint mobility, associated with swelling and increased volume of the knee. Because only 3 out of $6(50 \%)$ patients showed elevated body temperature (between $37.5^{\circ} \mathrm{C}$ and $39.2^{\circ} \mathrm{C}$ ), we concluded that the absence of fever does not completely exclude an infection. These results are concordant with Margaretten et al. [18], who reported a sensitivity of $57 \%$ for increased body temperature in their cases of septic arthritis. During the consultation, swelling of the knee, persistent effusion and increased local temperature were recorded. No fistulas were identified. J oint aspiration was performed for all patients at admission, for bacteriological tests.

Coagulase-negative staphylococci were most frequently pathogens in our study, followed by group $D$ Streptococcus and $E$. coli, which is comparable with what other studies found $[7,13,14,19-21]$. While $E$. coli is a pathogen often reported to pose problems in terms of its decreased susceptibility to antimicrobials [22], coagulasenegative staphylococci are rather known for their potential to form biofilm [12] and to express a specific aggressiveness pattern leading to chronic, at times subclinical, infections rather than acute fulminant ones [23]. The case of culture-negative infection identified in our study, could potentially have been due to the phenotypic pattern of small colony variants, which can be expressed by most germs responsible for septic arthritis, and which may require longer culture times [24]. Although there were some differences between the symptoms onset of each type of bacterial infection, this didn't affect the clinical course or the number of irrigation and debridement procedures. Whether the development of OA in long term outcome is linked to a certain type of bacterial infection, is still a matter of debate $[19,25,14]$.

The treatment protocols of septic arthritis following $\mathrm{ACL}$ reconstruction are conflicting in the literature. Graft and hardw are retaining is the first choice for most authors when they consider the graft functional. [7, 14, 20, 21, 26]. Others 
would rather advise that the graft and hardware be removed as soon as possible, minimizing the risk of persistent infection [13]. According to them, the indications of graft removal are: (1) elongated graft and non-functional during clinical and arthroscopic examination; (2) thick and purulent exudation adhered to the graft; and (3) persisting knee infection after repeated debridement [13]. Loosened hardware, tibial or femoral devices, are also concomitantly removed. We focused our approach on graft retention whenever possible, by arthroscopic procedures. However, in special cases with fulminant infection, arthrotomy can be taken into consideration. In our study, eradication of infection was achieved after one debridement with graft retention in 5 of 6 patients (83.3\%). One case necessitated 2 debridements and the graft was removed at the end, when a structural disruption of the graft was noted.

Antibiotic therapy is another controversial subject. Some authors suggest a minimum duration of 4 weeks [14, 25, 27], while others recommend longer periods of time, such as Indelli et al. [5] who suggested IV antibiotics for a duration of at least 6 weeks. Others authors like Wang et al. [27], recommended initial IV treatment for 2-3 weeks followed by transition to an oral regimen for an additional 2-3 weeks once CRP levels decrease to normal range.

In our cases, a length of maximum 4 weeks of IV antibiotic, with CRP normalization continued with another 2 weeks of oral administration was appropriate to eradicate all the infections without re-emergence.

The clinical and functional outcome of patients included in our study was good. The Lysholm Knee Scoring Scale and Tegner Activity Scale show ed good functional results (table 5). Despite the fact that literature reports good to excellent results, patients with infected $\mathrm{ACL}$ reconstruction had inferior clinical outcomes to those who didn't develop any complications after surgery, although the graft function was overall good [7, 20, 25]. In our series, at midterm follow-up (1 year), the functional status was good with the resuming of sports activities at a level close to preinjury status (recreational activities); none of the cases occurred in performance athletes. The articular mobility was within normal limits, without arthrofibrosis. After 1 year, the muscular force was still lower in the affected leg compared to the opposite leg compared to normal cases, without infection, where muscular strength is normal in the vast majority of cases.

The most common causes leading to functional limitations and revision surgery was attributed to stiffness and arthrofibrosis. In our series, in one case a feeling of

Table 5

CLINICAL OUTCOME

\begin{tabular}{|c|c|c|c|}
\hline Patient & LKSS & TAS & Rx \\
\hline$A^{2}$ & 96 & 6 & No \\
\hline B & 68 & 2 & No \\
\hline$C^{-1}$ & 98 & 5 & No \\
\hline$D$ & 99 & 6 & No \\
\hline$E$ & 89 & 4 & No \\
\hline$F$ & 96 & 5 & No \\
\hline
\end{tabular}

LKSS - Lysholm Knee Scoring Scale; TAS - Tegner Activity Scale; $\mathrm{Rx}$ - radiological osteoarthritis modifications instability occurred during sports activity at 10 months after eradication of infection. Clinically a slight positive anterior drawer sign can be noted;

The MRI exam shows the continuity of the graft in all cases, including the case with clinical instability. No signs of cartilage destruction were noted at least 2 years after the follow-up.

\section{Conclusions}

SCoagulase-negative staphylococci were the most commonly found pathogen (50\%). Our approach, with early diagnostic and fast intervention within the first few hours after symptom onset, with aggressive debridement, correlated with a targeted antibiotic treatment protocol can lead to graft retention and good functional results.

\section{References}

1. HIRSHMAN H.P., DANIEL D.M., MIYASAKA K. The fate of unoperated knee ligament injuries. In: Knee Ligaments: Structure, Function, Injury and Repair. New York, 1990, pp 481

2. AZAR F.M., ARTHUR S.T. Complications of anterior cruciate ligament reconstruction. Tech Knee Surg, 3, 2004, pp 238.

3. VAN TONGEL A., STUYCK J ., BELLEMANS I., VANDENNEUCKER $\mathrm{H}$. Septic arthritis after arthroscopic anterior cruciate ligament reconstruction: a retrospective analysis of incidence, management and outcome.J Sports Med, 35, nr. 7, 2007, pp 1059.

4. BENNER R.W., SHELBOURNE K.D., FREEMAN H. Infections and patellar tendon ruptures after anterior cruciate ligament reconstruction: a comparison of ipsilateral and contralateral patellar tendon autografts. Am J Sports Med, 39, nr. 3, 2011, pp 519.

5. INDELLI P.F., DILLINGHAM M., FANTON G., SCHURMAN D.J. Septic arthritis in postoperative anterior cruciate ligament reconstruction. Clin Orthop Relat Res, 398, 2002, pp 182.

6. FONG S.Y., TAN J.L. Septic arthritis after arthroscopic anterior cruciate ligament reconstruction. Ann Acad Med Singapore, 33, 2004, pp 228.

7. JUDD D., BOTTONI C., KIM D., BURKE M., HOOKER S. Infections following arthroscopic anterior cruciate ligament reconstruction. Arthroscopy, 22, 2006, pp 375.

8. BINNET MS BASARIR K. Risk and outcome of infection after different arthroscopic anterior cruciate ligament reconstruction techniques. Arthroscopy, 23, nr. 8, 2007, pp 862.

9. HOGAN C.J., FANG G.D., SCHELD W.M., LINDEN J., DIDUCH D.R. Inhibiting the inflammatory response in joint sepsis. Arthroscopy, 17, nr. 3, 2001, pp 311.

10. SCHUSTER P SCHULZ M, IMMENDOERFER M, MAYER P, SCHLUMBERGER M, RICHTER J. Septic arthritis after arthroscopic anterior cruciate ligament reconstruction: evaluation of an arthroscopic graft-retaining treatment protocol. Am J Sports Med, 43, nr. 12, 2015, pp 3005.

11.CALVISI V., LUPPARELLI S. C-reactive protein changes in the uncomplicated course of arthroscopic anterior cruciate ligament reconstruction. Int] Immunopathol Pharmacol, 21, nr. 3, 2008, pp 603. 12. NEGUT, A.C., CHIFIRIUC, M.C., SANDULESCU, O., STREINUCERCEL, A., OPREA, M., DRAGULESCU, E.C., GHEORGHE, I., BERCIU, I., CORALIA, B., POPA, M., OTELEA, D., TALAPAN, D., DOROBAT, O., CODITA, I., POPA, M.I., STREINU-CERCEL, A., Bacteriophage-driven inhibition of biofilm formation in Staphylococcus strains from patients attending a Romanian reference center for infectious diseases. FEMS Microbiol Lett, 363, nr. 18, 2016.

13. BURKS R.T., FRIEDERICHS M.G., FINK B., LUKER M.G., WEST H.S., GREIS P.E. Treatment of postoperative anterior cruciate ligament infections with graft removal and early reimplantation. Am J Sports Med, 31, 2003, pp 414.

14. MCALLISTER D.R., PARKER R.D., COOPER A.E., RECHT M.P., ABATE J. Outcomes of postoperative septic arthritis after anterior cruciate ligament reconstruction. Am J Sports Med, 27, 1999, pp 562. 
15.VIOLA R., MARZANO N, VIANELLO R. An unusual epidemic: staphylococcus negative infections involving anterior cruciate ligament reconstruction with salvage of the graft and function. Arthroscopy, 16, 2000, pp 173.

16. SONNERY-COTTET B., ARCHBOLD P., ZAYNI R., BORTOLLETTO J., THAUNAT M., PROST T. et al. Prevalence of septic arthritis after anterior cruciate ligament reconstruction among professionals athletes. Am J Sports Med, 39, nr. 11, 2011, pp 2371.

17. HANTES M.E., BASDEKIS G.K., VARITIMIDIS S.E., GIOTIKAS D., E PETINAKI., MALIZOSK.N. Autograft contamination during preparation for anterior cruciate ligament reconstruction. J Bone Joint Surg Am, 90, 2008, pp 760.

18. MARGARETTEN M.E., KOHLWES ] ., MOORE D., BENT S. Does this adult patientnhave septic arthritis? JAMA, 297, nr. 13, 2007, pp 1478. 19. MOUZOPOULOSG, FOTOPOULOS V.C., TZURBAKIS M. Septic knee arthritis following $A C L$ reconstruction: a systematic review. Knee Surg Sports Traumatol Arthrosc, 17, nr. 9, 2009, pp 1033.

20. SCHULZ A.P., GOTZE S., SCHMIDT H.G., JURGENS C., FASCHINGBAUER M. Septic arthritis of the knee after anterior cruciate ligament surgery: a stage-adapted treatment regimen. Am J Sports Med, 35, nr. 7, 2007, pp 1064.

21.TORRES-CLARAMUNT R., PELFORT X., ERQUICIA J ., GILGONZALEZ S., GELBER P.E., PUIG L. et al. Knee joint infection after $A C L$ reconstruction: prevalence, management and functional outcomes. Knee Surg Sports Traumatol Arthrosc, 21, nr. 12, 2013, pp 2844.
22. SANDULESCU, O., Global distribution of antimicrobial resistance in E. coli. Contemp Clin Pract, 2, nr. 2, 2016, pp 69.

23. SANDULESCU, O., BLEOTU, C., MATEI, L, STREINU-CERCEL, A., OPREA, M., DRÃGULESCU, E.C., CHIFIRIUC, C.M., RAFILA, A., PIRICI, D., TALAPAN, D., DOROBA, O.M., NEGU, A.C., OTELEA, D., BERCIU, I., ION, D.A., CODITÃ, I., CALISTRU, P.I., STREINU-CERCEL, A.,. Comparative evaluation of aggressiveness traits in staphylococcal strains from severe infections versus nasopharyngeal carriage. Microb Pathog, 14, nr. 102, 2016, pp 45.

24. PFORTNER H BURIAN MS, MICHALIK S, DEPKE M, HILDEBRANDT P, DHOPLE VM, PANE-FARRE J, HECKER M, SCHMIDT F, VOLKERA U. Activation of the alternative sigma factor $\mathrm{SigB}$ of Staphylococcus aureus following internalization by epithelial cells $A n$ in vivo proteomics perspective. Int J Med Microbiol, 304, 2014, pp 177.

25. SCHOLLIN-BORG M., MICHAELSSON K., RAHME H. Presentation, outcome, and cause of septic arthritis after anterior cruciate ligament reconstruction: a case control study. Arthroscopy, 19, nr. 9, 2003, pp 941.

26. PETERSEN W., HERBORT M., HOYNCK E., ZANTOP T., MAYR $H$. Stage adapted treatment of infection after reconstruction of the anterior cruciate ligament. Oper Orthop Traumatol, 26, nr. 1, 2014, pp 63. 27. WANG C., AO Y., WANG J., HU Y., CUI G., YU J. Septic arthritis after arthroscopic anterior cruciate ligament reconstruction: a retrospective analysis of incidence, presentation, treatment, and cause. Arthroscopy, 25, nr. 3, 2009, pp 243.

Manuscript received: 20.08 .2018 